\title{
Analyzing the Social License to Operate in International Investment Law
}

\author{
Rudresh Mandal*
}

\begin{abstract}
A small segment of Investor-State Arbitration flows from the consequences of resistance by the local population (particularly, indigenous people) against the particular investment, and the concerned State cancelling permits granted earlier, precluding all future activities of the investor. This paper seeks to argue that when faced with an investment treaty dispute of this nature, arbitrators should (and indeed may be required to) reflect on the Social License to Operate (SLO) as a part of the applicable law. It aims at creating a framework within which the Social License to Operate should be conceptualized by investment tribunals in the future. The article first examines the nature of the social license to operate and then goes on to highlight its existence in relevant bodies of international law. Thereafter, the article seeks to analyze its use in past investment tribunals, such as the award laid down in Bear Creek Mining v. Peru, and uses this analysis as a springboard to construct a way forward for future applications of the concept.
\end{abstract}

Keywords: Corporate Social Responsibility, Indigenous people, International Conventions, Investor-State Arbitration, Investment Tribunals

\section{Introduction}

The concept of the Social License to Operate (SLO) has thus far been predominantly located in the social sciences, rather than the

* National Academy of Legal Studies and Research, Hyderabad, India; rudreshm.97@gmail.com 
legal field. Tracing its origins to the circumstances surrounding the mining industry, especially owing to the societal pressure exerted on the industry due to its adverse environmental and social consequences, ${ }^{1}$ signs of the SLO are now visible across industries and even in law, in concepts such as Corporate Social Responsibility (CSR). Karin Buhmann argues that the SLO is experiencing a 'juridification' of sorts, wherein societal expectations from businesses are couched in the language of the law, indicating cross-fertilization between law and the ethics of business. ${ }^{2}$ Therefore, it is imperative that we understand the concept of the SLO from a broad perspective, drawing from international finance law, environmental law and human rights law. ${ }^{3}$ The right of the affected public (including indigenous people) to participate in decision-making processes, the right to free, prior and informed consent and sustainable development are avenues in conceptualizing the SLO itself. The nature of the SLO in the United Nations Guiding Principles on Business and Human Rights, ${ }^{4}$ signifies the 'juridification' of the field in the intersection of business and human rights, whether it be the SLO or CSR. The SLO has also been recognized in international investment law, evidenced by the rulings of certain investment tribunals, most notably in Bear Creek Mining v. Peru, which will be examined in greater detail.

1 Temple Stoellinger, L.S. Smutko, J.M. Western, Collaboration through NEPA: Achieving a Social License to Operate on Federal Public Lands, 39 PUB LAND AND RESOURCES LAW REV 203, 210 (2018).

2 Karin Buhmann, Public Regulators and CSR: The "Social Licence to Operate, 136 JOURNAL OF BUSINESS ETHICs 699, 699.

3 Don Smith, Social License to Operate: Hydraulic Fracturing-Related Challenges Facing the Oil \& Gas Industry, 1 ONE J 81, 90-93 (2015).

${ }^{4}$ Office of the United Nations High Commissioner for Human Rights, The Corporate Responsibility to Respect Human Rights: An Interpretative Guide. https://www.ohchr.org/Documents/Publications/HR.PUB.12.2_En.p df

5 Bear Creek Mining v Peru, ICSID Case ARB/14/21, Award (30 November 2017) 
Of particular relevance to investment arbitration is the potential of the SLO to mitigate the legitimacy crisis it finds itself mired in ${ }^{6}$. This is primarily owing to the fact that the SLO is determined by ideas of democratic participation, societal acceptance and trust. The implication of the necessary importance which will have to be granted to the SLO is that, arbitrators will not have to consider aspects of the SLO as a portion of the law applicable to the substance of the dispute. By weaving in the core values of the global community and the aspirations and demands of a plethora of participants in arbitral awards, arbitrators can catapult the international investment mechanism into a new era of social legitimacy and approval. The current debate in the field of international investment law arises from the tension between the requirements of the host State to protect legitimate interests of local communities on the one hand, while on the other, simultaneously creates an appropriate environment for international investment. ${ }^{7}$

\section{Examining the Nature of the SLO}

The Minerals Council of Australia defines the SLO as an unwritten social contract for which the nature of a license must be earned and maintained on grounds of stable performance, backed by the trust of the society. 8 The absence of an SLO might endanger progress of the project, due to protests and shifting of employees to other sustainable corporate houses - all this notwithstanding obtaining of legal licenses. Similarly, Lindahl defines an SLO as a just balance between competing interests of society, ultimately permitting certain industrial activities to prosper. ${ }^{9}$ The SLO limits the area within which a company may conduct its activity, since social

6 See generally Thomas Dietz, The legitimacy crisis of investor-state arbitration and the new EU investment court system, 26 REV. OF INT'L POL. ECON 749 (2019).

7 MM Barnes, The Social License to Operate: An Emerging Concept in the Practice of International Investment Tribunals, 10 JOURNAL OF INT'L DisPuTE SETTLEMENT 328, 328-330 (2019).

8 MCA, Enduring Value Framework (Minerals COUNCIL OF AUsTRALIA), https:/ / minerals.org.au/enduring-value-framework.

${ }^{9}$ Hans Lindahl, One Pillar: Legal Authority and a Social License to Operate in a Global Context, 23 IND J GLOBAL LEGAL STUD 201, 210-213 (2016). 
expectations require companies to restrain themselves from activities regarded as undesirable, irrespective of their presence in law. The absence of an SLO is usually felt when projects are shutdown owing to a fragile socio-political atmosphere, caused in turn by manifestations of active dissent, boycotts, protests and blockades. ${ }^{10}$

Providing an accurate definition of the concept of the SLO is no simple task due to the fact that the concept still does not possess a stronghold in the legal circuit. This is exacerbated by the fact that the process of acquisition and maintenance of an SLO involves a spectrum of actors. The essence of the SLO lies in the understanding that the stakeholders have the real power and that communities have as much authority as governments, in granting permissions or licenses. ${ }^{11}$ In a similar vein, Smits et al. ${ }^{12}$ posit that in order for a particular commercial activity to be performed, a company must procure three licenses - a legal license, wherein a license located in the regulatory framework of the host State is granted by State authorities, in accordance with established processes, a political license, where the license of authority is granted by the concerned Government to a company to engage in the said commercial activity. Finally, a social license, whose premise invariably draws from the social contract theory, with the implication that even the mightiest States have realized that they require something more than just a mere political license to carry out a commercial activity that may be problematic for a certain segment of their citizenry. The social license is by far the most difficult to define of the three-strand SLO model, outlined by Smits et al. 13

10 Jennifer Howard-Grenville et al, Constructing the License to Operate: Internal Factors and Their Influence on Corporate Environmental Decisions, 30 LAW \& POLICY 73, 84 (2008).

$11 \mathrm{R}$ Boutilier, FAQs about the SLO, 32 IMPACT ASSESSMENT AND PROJECT APPRAISAL 263, 264-65 (2014).

12 CA Smits, van Leeuwen \& van Tatenhove, Oil and Gas Development in Greenland: A SLO, Trust and Legitimacy in Environmental Governance, 53 RESOURCES POLICY 112, 113 (2017),

$13 \mathrm{Id}$. 
The above definitions yield a number of features of the SLO. Firstly, since the SLO is an unwritten contract, a visit to a Government office and filing of an application cannot help in procuring it. Companies require something greater than mere money to organically integrate into the societies within which they operate. ${ }^{14}$ The SLO is indeed difficult to obtain, for unlike the legal license, there exists no pre-defined checklist which a company must fulfill. Yet, not possessing or losing the SLO may have adverse impacts on the company, whether in terms of legal sanction, financial or reputational loss. ${ }^{15}$ Consequently, the interaction between the three strands of the SLO model cannot be denied. For instance, the social license is strengthened by the legal license, since the latter provides civil society with the tools to question and pressurize companies. On the flipside, the legal license is enlarged by the social license, since societal pressure on the legislature often culminates in better enactment, increased monitoring and greater enforcement of laws.

The grant and maintenance of the SLO hinges on the company obtaining continued acceptance or approval of the local population and other relevant stakeholders. Thomson and Boutilier have argued that 'approval'16 (to have favorable regard, agreeing to, or being pleased with) of the community satisfies a higher standard than mere 'acceptance' (tolerate, agree or consent to). Every effort should be taken to widen the range of stakeholders involved in this process of acceptance and approval, as certain stakeholders may remain marginalized and silent in the beginning and the fulfillment of corporate objectives are often limited by relational legacies. Additionally, while the community's acceptance of a particular project is non-negotiable, the greater standard of 'approval' helps legitimize not only the project, but the industry in its entirety. Beyond acceptance, at the highest level of the SLO, stakeholders

${ }^{14}$ Chilenye Nwapi, Can the Concept of Social Licence to Operate Find Its Way into the Formal Legal System, 18 FLINDERS LAW JOURNAL 359, 361-364 (2016).

${ }^{15}$ Gary Lynch-Wood, The Social License as a Form of Regulation for Small and Medium Enterprises, 34 JOURNAL OF LAW AND SOCIETY 321, 341 (2007).

16 Ian Thomson \& R Boutilier, Social License to operate, P. Darling ed., SME Mining Engineering Handbook, 1779 (2011). 
may perceive themselves as joint owners of the project. They also create a pyramidic model of the SLO, highlighting the various stages and boundaries of the SLO.17

Implicit in the concept of an SLO lies a continuing vetoing procedure by the affected community and additional stakeholders. In other words, a company's obligation does not end with obtaining the SLO, but extends to maintaining it over the course of their activity. Specific to the mining sector, the SLO assumes initial relevance during the commencement of explorative activity and spans the life-cycle of the mining project, from mine construction to operation, to closure and sometimes post closure. Obtaining and maintaining the SLO cannot have a fixed formula, for it is context specific, varying across distinctive communities with their own philosophies. ${ }^{18}$ For instance in the Bear Creek case ${ }^{19}$, though there were twenty one communities, they had a joint decision-making system, and only five (the Huacullani, Ingenio, Chllocolo, Condor de Acongua and Ancomarca communities) were consulted. At a more general level, plenty of tribes in India such as the Dongria Kondh, attribute religious importance to specific areas, and if these areas are sought to be brought within the fold of the industrial project at a later stage, the SLO would still apply at this stage, and consultation is deemed to be a pre-requisite.

Notwithstanding the SLO's unwritten, intangible and informal content, it can still be enforced legally, since the SLO relies on reputation capital. The credibility which comes along with this type of capital, reduces the cost of risk linked with acquiring societal acceptance, apart from the favor of the government. In order to legally enforce the SLO, countries often create an enabling framework for projects revolving around community consultation..$^{20}$ For example, India does possess a legislative

17 Id.

${ }^{18} \mathrm{Id}$.

19 Bear Creek Mining v Peru, ICSID Case ARB/14/21, Award (30 November 2017)

20 Claudia Posleman, Social License to Operate in the Mining Industry: The Case of Peru, 37 IMPACT ASSESSMENT AND PROJECT APPRAISAL, 480, 485 (2019). 
framework on land rights (Right to Fair Compensation and Transparency in Land Acquisition, Rehabilitation and Resettlement Act, 2013, most notably) and environmental protection laws (the Environmental (Protection) Act, 1986 from which companies are required to conduct Environmental Impact Assessments, (a component of which is consultation of affected people), which require companies to consult stakeholders, and thereafter obtain environmental clearances and licenses from the state, before commencing these operations. However, in India, non-compliance with the consultative activity is a common phenomenon. These consultative activities constitute a pre-requisite for gaining appropriate legal and environmental clearances. Legal sanctions aside, the SLO may also be applied from an economic perspective, such as the use of consumer boycotts.

\section{Understanding the SLO from the Perspective of International Law}

The field of international investment law is not closed and is one that requires harmonious interpretation with other provisions of international law, of which it is a part. The aim of the article now is to facilitate a more nuanced understanding of the SLO. This is done by analyzing the decisions of investment tribunals and the use of the SLO in their judgements. The SLO is a reflection of continuing 'acceptance' and/or 'approval' of a particular corporate project by the community and other relevant stakeholders. ${ }^{21}$ Consequently, the principle of public participation shares common ground with the SLO. Public participation in turn, includes the right to access information, participate in decision-making processes and access avenues of justice, with the aim of protecting living conditions and limiting environmental harm. ${ }^{22}$ The right to public participation is

21 Alonso Gurmendi, Indigenous Social License in Investment Projects: A Pending Challenge in ISDS (OPINIOJURIS, APRIL 4, 2019), opiniojuris.org/2019/04/08/indigenous-social-license-in-investmentprojects-a-pending-challenge-in-isds/.

22 See generally Lavanya Rajamani \& Shibani Ghosh, PUBLIC PARTICIPATION IN INDIAN ENVIRONMENTAL LAW IN BARRY BARTON ET AL ED. SHARING 
found in a number of international environmental instruments, from the Aarhus Convention, $1998^{23}$ to the World Heritage Convention, $1972^{24}$ and the UNECE Convention on Environmental Impact Assessment in a Transboundary Context of 1991.25

The SLO may also be located within the concept of sustainable development, defined broadly as the understanding that the path to development must encapsulate the 'needs of the present without compromising the ability of future generations to meet their own needs' (inter and intra generational equity) ${ }^{26}$. Corporate enterprises are now required to respect human rights and the environment, given the environmental degradation and cultural disruption brought on by their activities. ${ }^{27}$ While doubts have been cast on the status of sustainable development as a rule of customary international law, it still forms a part of three hundred international conventions. ${ }^{28}$ Also found in the practice of international courts and tribunals, the International Court of Justice (ICJ) in GabcikovoNagymoros case $^{29}$ stated that the goals of economic development

THE COSTS AND BENEFITS OF ENERGY AND RESOURCE ACTIVITY: LEGAL CHANGE AND IMPACT ON COMMUNITIES (2016).

23 Convention On Access To Information, Public Participation In DecisionMaking And Access To Justice In Environmental Matters, 25 June 1998, https://www.unece.org/fileadmin/DAM/env/pp/documents/cep43 e.pdf

24 UNESCO, Convention Concerning The Protection Of The World Cultural And Natural Heritage, 16 Nov. 1972, https://whc.unesco.org/archive/convention-en.pdf

25 UNECE, Convention On Environmental Impact Assessment In A Transboundary Context, 1991, https://www.unece.org/fileadmin/DAM/env/eia/documents/legalt exts/Espoo_Convention_authentic_ENG.pdf

26 United Nations, Report of the World Commission on Environment and Development: Our Common Future (UN, 1987) https:// sustainabledevelopment.un.org/content/documents/5987ourcommon-future.pdf.

${ }^{27} \mathrm{Id}$.

$28 \mathrm{Id}$.

29 Gabčikovo-Nagymaros Project, Hungary v Slovakia, Judgment, Merits, ICJ GL No 92, (1997) ICJ Rep 7, (1997) ICJ Rep 88, (1998) 37 ILM 162, ICGJ 66 (ICJ 1997), 25th September 1997, International Court of Justice. 
and environmental protection must coalesce, and their duality is efficiently captured in the concept of sustainable development. The SLO additionally finds resonance in the UN's Sustainable Development Goals, particularly the eighth goal, which fosters 'sustained, inclusive and sustainable economic growth' and the duty of companies in meeting this goal ${ }^{30}$. The eighth goal represents the inclusivity of sustainable development and is a facet of the SLO, for any development that negates the voice of affected communities cannot be sustainable.

The responsibility imposed on companies to protect human rights as part of their corporate duty, is also enshrined in the United Nations Guiding Principles (UNGPs), and M.M. Barnes argues that the SLO played a crucial role as part of the discursive process in the build-up to promulgation of the UNGPs. ${ }^{31}$ John Ruggie's report to the Human Rights Council in $2009^{32}$ also stated that companies have now understood that a legal license may not be enough, and an SLO is absolutely essential for determining adherence to social norms that influence the success of the enterprise. The SLO also echoes in the concept of Free, Prior and Informed Consent (FPIC), one that was extensively discussed in Prof. Sands' dissent in Bear Creek Mining v. Peru ${ }^{33}$. At one level, both the right to FPIC and the SLO seek to attain the support of communities and stakeholders for a particular corporate project. At another level, however, there are certain differences between both concepts. The SLO necessitates interaction with the community as a whole, and not just indigenous people as envisaged by FPIC. ${ }^{34}$ Further, since international law provides the protection of the same to indigenous people, its violation or non-compliance attaches itself to the State and not

30 Goal 8, Transforming our world: the 2030 Agenda for Sustainable Development,

https:// sustainabledevelopment.un.org/post2015/transformingourwo rld

${ }^{31}$ MM Barnes, supra note 7

$32 \mathrm{Id}$.

33 Bear Creek Mining v Peru, ICSID Case ARB/14/21, Award (30 November 2017)

${ }^{34}$ MM Barnes, supra note 32 
companies, although it may form part of the legal license acquired by the company.

In terms of time, the FPIC is far more limited, for it only applies during the pre-project stage and during entry into the land, whereas the SLO is an ongoing process of acceptance, which has to be maintained over the course of the project. ${ }^{35}$ The amorphous nature of the SLO, therefore, is one which suffers from definitional ambiguity, touching upon fields of human rights, environmental protection, the right to FPIC and public participation. In fact, the composite character of the SLO may result in it forming a part of transnational public policy, owing to its nature as a meta-principle, used by Boyle and Freestone ${ }^{36}$, to describe the need for sustainable development. Yet, these meta-principles are of significance, for they claim normative status as a part of judicial reasoning.

\section{The SLO and its Interface with Investment Treaty Law}

The inclusion of matters concerning sustainable development, human rights and its interaction with industrial activity in Bilateral Investment Treaties (BITs) can broadly be divided into two phases. The Organization for Economic Cooperation and Development (OECD), conducted a survey on investment treaty law \& sustainable development ${ }^{37}$ in 2014, analyzing 2107 BITs in the process. It found that matters of social importance were barely mentioned in BITs, prior to 2008. This was primarily because BITs create an asymmetrical relationship between the investor company and the host State. Investors were traditionally only vested with rights, devoid of any corresponding duty/obligation to protect

$35 \mathrm{Id}$.

36 AlAN BOYlE AND DAVID FREESTONE, INTERNATIONAL LAW AND Sustainable DeVElopment: PAST ACHIEVEMENTS AND Future CHALLENGES, 31-34 (1999).

37 Gordon, K., J. Pohl and M. Bouchard, Investment Treaty Law, Sustainable Development and Responsible Business Conduct: A Fact Finding Survey (OECD WORKING PAPERS ON INTERNATIONAL INVESTMENT, 2014) http:/ / dx.doi.org/10.1787/5jz0xvgx1zlt-en 
human rights. 38 The absence of these matters of sustainable development was also felt in the decisions of investment tribunals, which were not required to consider them in their reasoning, since they were missing from the BITs themselves.

Gradually however, both scholars and investment tribunals began to map the relationship between foreign investment and human rights/environmental protection. 75\% of the BITs between 2008 and 2012, and an even greater percentage between 2012 and 2013, utilize language revolving around responsible conduct of corporations, geared towards securing human rights and sustainable development ${ }^{39}$. The 2018 Model BIT of the Netherlands explicitly references soft law instruments, such as the United Nations Guiding Principles on Business and Human Rights (UNGP), and the OECD Guidelines for Multinational Enterprises, both of which concern the investors' duty to protect human rights. Article 23 of this BIT goes even further and empowers the arbitral tribunal to consider non-compliance with the UNGPs or the OECD Guidelines, while determining the quantum of damages ${ }^{40}$.

More than the BITs themselves, investment tribunals seeking to mitigate the legitimacy crisis plaguing the field, have taken it upon themselves to navigate the interface between investment law and sustainable development. Steininger ${ }^{41}$ takes this trend a step forward and suggests that sustainable development, human rights and responsible business conduct will occupy a pivotal position in the debate on the future of investment arbitration. The premise of this thought is that, by incorporating the SLO into arbitral awards, tribunals change the practice towards ensuring the legitimacy of foreign investment and increase their own legitimacy, by

38 Luke Peterson and Kevin Gray, International Human Rights in Bilateral Investment Treaties and in Investment Treaty Arbitration (IISD, APRIL 2003) https:// www.iisd.org/ pdf/2003/ investment_ int_ human_ rights_bits.pdf.

39 Pohl and Bouchard, supra note 37

40 Art. 23, Netherlands Draft Model BIT, https://globalarbitration review.com/digital_assets/820bcdd9-08b5-4bb5-a81e-d69e6c6735ce/ Draft-Model-BIT-NL-2018.pdf

41 Bruno Simma, Foreign Investment Arbitration: A Place for Human Rights, 3 ICLQ 573, 575-580 (2011). 
safeguarding the rights of citizens and by elaborating the principles of justice beneath their rulings. This strand of thought, along with the composite nature of the SLO and its permeation into international law, is visible in the Tribunal's holding in Urbaser $v$. Argentina. 42 The Tribunal rejected the Claimant's assertion that first, international investment law did not prescribe any obligation on investor companies and second, that international investment law was a closed system, and thereby tribunals were precluded from using other principles of international law as aids to interpretation. The Tribunal specifically referred to the UNGP, the Universal Declaration of Human Rights (UDHR) and the International Covenant on Economic Social and Cultural Rights (ICESCR) in conceptualizing the responsibility of companies to safeguard human rights. For purposes of the SLO, the importance of this case stems predominantly from its holding that international investment law is not a closed system, thereby allowing the SLOs considerations of sustainable development and human rights to integrate with the field of investment law.

The first case to discuss the SLO extensively was Bear Creek Mining v. Republic of Peru. ${ }^{43}$ While the Tribunal had to consider other aspects, such as the acquisition of the mining license in the name of a Peruvian employee of Bear Creek, and not Bear Creek itself, in order to circumvent the requirement of proving public necessity ${ }^{44}$ and the supposed illegality of this mechanism, owing to considerations of space and immediate relevance, this paper will focus only on the SLO aspects of the Award. In the backdrop to the project, Bear Creek obtained the legal license to operate the Santa Ana Mining Project through Supreme Decree 083, issued by an order passed by the Peruvian Council of Ministers, declaring the Project as a public necessity, allowing Bear Creek to enjoy all rights arising out of the concession.

A couple of years into the mining project, wide cracks began to emerge in the relationship between Bear Creek and the

42 Urbaser S.A. and Consorcio de Aguas Bilbao Bizkaia, Bilbao Biskaia Ur Partzuergoa v. The Argentine Republic, ICSID Case No. ARB/07/26

43 BEAR CREEK, supra note 5.

$44 \mathrm{Id}$. 
communities affected by the project. In a severe deterioration of their relationship, Bear Creek's employees were attacked and held hostage when they sought to describe the environmental management program of the company. The concerns of the local communities were that the benefits of the project would not be distributed in an equitable fashion between the communities living in close proximity of the Santa Ana mine. Responding to this social crisis, through a series of community development agreements, Bear Creek succeeded in obtaining the acceptance of some of the affected communities, but not all. However, owing to rising violence and increasing social unrest, the Peruvian Government passed Decree 032, which effectively revoked the rights granted to Bear Creek under the earlier Decree 083. Consequently, Bear Creek brought a claim of damages for indirect expropriation of its investment and instituted arbitration proceedings under the PeruCanada FTA.

Peru alleged that the Santa Ana Mining Project lacked an SLO and hence Bear Creek directly contributed to the social dissent leading to the issuance of Decree 032. The question framed by the Tribunal was whether the actions of the Claimant in seeking to obtain a Social License were legal, and whether the Claimant was attributable to the performance of these acts..$^{45}$ The majority, in its award reiterated that every applicable international instrument mandates consultation with affected communities in order to obtain their consent, taking into consideration the lack of a definition of the SLO in international law and citing the UN Declaration on the Rights of Indigenous People. While for the Tribunal it was undeniable that Bear Creek could have undertaken greater effort in its community outreach and development endeavors, it remained to be seen if greater outreach was legally demanded and whether there was a causal link between its absence and the social dissent. The majority then based its decision on the reasoning that the Government of Peru had, until the outbreak of social violence, approved and supported the community outreach and consultation efforts, without any objection. Consequently, Bear Creek had fulfilled all legal conditions vis-à-vis its community 
consultation and public participation activities. Given Peru's continued support to Bear Creek's consultative activities, it was now stopped from claiming that the impugned conduct was inadequate and caused social unrest in the Santa Ana area.

The SLO however found greater discussion in Professor Sands' dissenting opinion in Bear Creek. In his opinion, Bear Creek had significantly contributed to the unrest, since it had failed to acquire and maintain an SLO, and its levels of preparation for investing in a land traditionally occupied by a tribal population, were insufficient. He went on to extensively refer to Urbaser $v$ Argentina ${ }^{46}$ and the International Labour Organization (ILO) Convention 169 (Concerning Indigenous and Tribal Peoples) 47 and noted that though Convention 169 did not attach any obligation on private foreign investors, the principles contained therein must inform any interpretation of the Canada-Peru Free Trade Agreement (FTA), since the applicable law in the FTA included applicable rules of international law. Given Convention 169's incorporation into Peruvian domestic law, it could be considered in determining the question of Bear Creek's discharge of its obligation to engage in prior consultation with local tribal communities. In their rejoinder to Prof. Sands, the majority highlighted that the reach of ILO Convention 169 was limited only to States and not private entities. Additionally, the affected tribal communities were not respondents in the arbitration, and instead it was the Government of Peru whose conduct the Tribunal had to adjudicate on. ${ }^{48}$ The majority's reasoning exhibits the differences that often arises between the interests of the indigenous communities affected by foreign investment on the one hand, and the agents of the host State whose behavior is subject to the rigors of investment treaty law. ${ }^{49}$

\footnotetext{
46 Urbaser, supra note 42

47 Convention C169-Indigenous and Tribal Peoples Convention, 1989 (No 169).

${ }^{48}$ Bear Creek, dissent, supra note 5.

${ }^{49}$ Joshua Paine, Case Comment on Bear Creek Mining Corporation v. Republic of Peru, ICSID REVIEW 1, 2-6 (2018).
} 
The definitional ambiguity of the SLO, however, surfaced in the majority opinion of Bear Creek ${ }^{50}$, for they combined the concept of the SLO with the FPIC, as mandated by the United Nations Declaration on the Rights of Indigenous Peoples (UNDRIP) and ILO Convention 169. The community activities undertaken by Bear Creek - the public meetings and workshops, were all pre-requisites for obtaining the FPIC, and not the SLO, which as indicated previously, is far wider in substantive scope and time than the FPIC. For instance, the majority considered it sufficient that Bear Creek consulted and held meetings with five of the twenty one affected communities, notwithstanding the fact that the affected tribe functioned as a collective social unit with a joint decisionmaking system. The SLO by its very nature necessitates broad approval of a project by the affected community. ${ }^{51}$ Questions may also be raised on whether Bear Creek crossed the legitimacy boundary stage of the SLO, since a degree of mistrust with regard to its true intentions arose when its Peruvian employee (in whose name the mining approval was sought to be granted) did not disclose her relationship with the company. Finally, while the Majority reasoned that the obligations of international law attach themselves to States and not private foreign investors, the State cannot be expected to hold the hand of the investor in obtaining the SLO. Its duty lies in creating a domestic framework which facilitates the implementation of the international obligations of the State. From an SLO perspective, the majority reasoning was flawed in its usage of the Canada-Peru FTA as an insurance policy justifying the lack of preparation by Bear Creek and its inability to obtain an SLO. 52

\section{Conclusion}

At the outset, it is incumbent on investment tribunals to define the SLO and elucidate its components. The majority in Bear Creek recognised that the SLO is still not defined in international law, and therefore the writing and opinion that exists in the social sciences

\footnotetext{
${ }^{50}$ Bear Creek, supra note 5

51 Id.

${ }^{52}$ BEAR CREEK, dissent, supra note 5.
} 
must be taken as a foundation on which the legal understanding of the SLO is constructed. The legal construction of the SLO has already begun, with its traces being located in the legal frameworks on FPIC, public participation, sustainable development and CSR. ${ }^{53}$ Investment tribunals must also seek to ensure that the SLO is not confused with similar phenomena like the FPIC, which are limited in scope. The majority in Bear Creek blurred the distinction and in doing so, reached an end incompatible with the 3-strand model of the SLO. ${ }^{4}$ The consequences of this blurring are significant, for it not only hurts the legitimacy of the particular investment, but also accentuates the legitimacy of the field of investment law. ${ }^{55}$

It is imperative that due attention be paid to the stage the SLO has reached. If the foreign investor were to contend with protests and dissent from the conceptualization of the project itself (or its initial stages), the quantum of damages flowing from expropriation must be diminished, in a manner consonant to Prof. Sands' dissent in Bear Creek. Similarly, if the SLO had been obtained initially, but could not be maintained through the project, the calculation of damages must reflect this. 56 The quantum of damages should be determined in proportion to the level of SLO that the foreign investor has attained. If the legitimacy boundary has been crossed, a greater quantum of damages as compensation may flow therefrom, and an even higher amount upon crossing the credibility boundary.

53 Herny Burnett \& Fernando Rodriguez Cortina, Arbitration of Social Disputes in Connection with Mining Projects (GLOBAL ARBITRATION REVIEW)

https://globalarbitrationreview.com/chapter/1194143/arbitration-ofsocial-disputes-in-connection-with-mining-projects.

54 Dante Figueroa, The "Social License to Operate" and "ius imperium" in treaty-based non-precluded measures provisions: The case of Latin America (THOMSON REUTERS ARBITRATION BLOG, MAY 2016) arbitrationblog.practicallaw.com/the-social-license-to-operate-and-iusimperium-in-treaty-based-non-precluded-measures-provisions-thecase-of-latin-america/.

55 Susan Franck, The Legitimacy Crisis in Investment Treaty Arbitration: Privatizing Public International Law Through Inconsistent Decisions, 3 TDM 111 (2005).

${ }^{56}$ M.M. Barnes, supra note 7. 
A concept that has thus far evaded the eye of international investment tribunals, the SLO has gradually begun to emerge in the practice of investment law. Although there exists confusion in the manner of approaching or characterizing the SLO, this paper has attempted to provide clarity with regards to the legal understanding of the SLO. From an Indian perspective, at one level, it is crucial that limited concepts like FPIC and sustainable development are actually adhered to. SLO is also the manifestation of the social responsibility of corporations and the original broader philosophy of CSR was to focus on how profits are made, and not just complying with CSR expenditure norms. The Indian government ought to require investors to think in broader terms of the SLO, and it is indeed true that they will have to appropriately define the SLO and mandate that this SLO needs to be respected at every stage of the project. India's legislation on land rights, tribal rights, forest rights and environmental law as well, contain elements of the SLO within itself. This needs to be spelt out as constitutive elements of the SLO for progress to be made. Indeed, given the wide range of concepts and laws that the SLO touches upon, an exact definition may not be possible, and scholars and practitioners alike may have to describe the concept as a composite meta-principle belonging to the sphere of transnational public policy. The importance of the SLO cannot be over-stated, for it enables a meaningful conversation between the often-clashing imperatives of investment law and society and in the long run, assuages the legitimacy concerns of the field. 